\title{
Breeding Ecology of Cinereous Vulture in Tien-Shan Mountailns, China
}

\section{ГНЕЗДОВАЯ БИОЛОГИЯ ЧЁРНОГО ГРИФА В ТЯНЬ-ШАНЕ, КИТАЙ}

\author{
Roller MaMing, Xu Liu, Shuchao Wang, Daoning Wu (Xinjiang Institute of Ecology and \\ Geography, Chinese Academy of Sciences, Urumqi, Xinjiang, China) \\ Роллер МаМинг, Сюй Лю, Шучао Ван, Даонинг Ву (Синьцзянский институт экологии \\ и географии, Китайская академия наук, Урумчи, Синьцзян, Китай)
}

\section{Contact:}

Roller MaMing

Xinjiang Institute

of Ecology and

Geography,

Chinese Academy of Sciences,

No. 818, Beijing Road, Urumqi, 830011.

Xinjiang, China

tel.: +869917885 363

maming@ms.xjb.ac.cn

\section{Резюме}

В 2016-2017 гг. мы наблюдали 4 гнезда чёрных грифов (Aegypius monachus) в центраяьной части Тянь-Шаня в Синьцзяне, на запаце Китая, и прослеживаяи одну молодую птицу с помошью GPS/GSM трекера. Основным методом полевой работы было Алительное наблюдение за гнёздами и описание поведения. Продолжительность полевых работ составила около 40 Аней и более 500 часов наблюдений. Все гнёзда грисоов были построены на восточно-ориентированных скалах на высоте 2300-2900 м наА ур. м, расстояние межАу ними составило 1-3 км. Места Аля гнёзд - открытые и крутые уступы, наружный диаметр гнёзд - 1,1-1,6 м. Во всех наблюдаемых гнёздах клацка состояла мишь из одного яйца $(n=4)$. Период насиживания миися 52-56 дней, птенец вылуплялся в середине апреля. Вес птенцов в среднем составлял: после вылупления - 160 г, 17 мая - около 1,50 кг, 14 июня - 5,65 кг, 14 июля - 8,56 кг (близок к весу взрослых). Период выкармливания птенцов очень дминный - 90-105 дней в гнезде, и продолжается после вылета птенцов до октября. Недостаток пиши является одной из причин низкого успеха размножения чёрного гриса.

Кяючевые слова: чёрный гриф, Aegypius monachus, выбор места мял гнезда, успех размножения, питание, Тянь-Шань.

Поступима в реАакцию: 23.12 .2017 г. Принята к публикации: 30.12 .2017 г.

\section{Abstract}

During 2016 and 2017, we observed 4 nests of the Cinereous Vulture (Aegypius monachus) in the middle of the Tien Shan Mountains, the west of China, and tried to follow them by the GPS/GSM dataloggers. We continuously observed nesting birds and recorded their behavior. The duration of the field works was about 40 days that makes in total more than 500 hours. The results showed that all nests of the vultures were located on the eastern slope of cliffs on the altitude of $2300-2900$ meters, with the distance between nests is $1-3 \mathrm{~km}$. Nests were built on the open and steep ledges with the outer diameter of the nest is 1.1-1.6 m. All clutches consists of only one egg $(n=4)$, the incubation period was 52-56 days, and the nestlings hatched in the middle of April; the medium weight of newly hatched nestlings was $160 \mathrm{~g}$. In May $17^{\text {th }}$, their weight increased to $1.50 \mathrm{~kg}$, in June $14^{\text {th }}-$ to $5.65 \mathrm{~kg}$, and in July $14^{\text {th }}$ the weight of young birds was about $8.56 \mathrm{~kg}$ (close to the adult's weight). The brooding period in this species is very long - nestlings stayed for 90-105 days in the nest, and continued to be fed by adult birds till October. Lack of food is one of the main reasons for low reproductive success in this species.

Keywords: Cinereous Vulture, Aegypius monachus, nest-site selection, reproductive success rate, feeding, Tien Shan Mountains.

Received: 23/12/2017. Accepted: 30/12/2017.
Гриср (Aegypius monachus) на гнезде. Апрель 2016 г. Фото МаМинга.

Cinereous Vulture (Aegypius monachus) in the nest. April, 2016. Photo by MaMing.

DOI: 10.19074/1814-8654-2017-35-252-259

\section{Введение}

Чёрный гриср (Aegypius monachus) крупный пахаиьшик, отнесённый в Китае во вторую природоохранную категорию (Yе, 1991; MaMing, Xu, 2015). Тем не менее, китайцы мамо знают об этом виде, например,

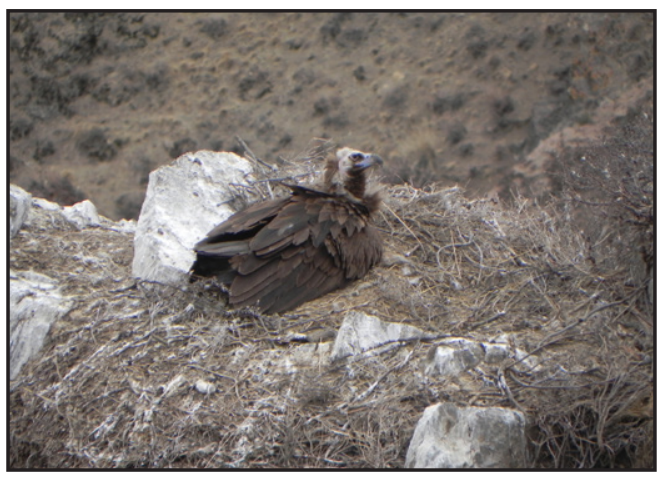

\section{Introduction}

The Cinereous Vulture or Eurasian Black Vulture (Aegypius monachus) is a large scavenger that enlisted as a second-class protected species in China (Ye, 1991; MaMing, Xu, 2015). However, little is known about this bird among Chinese people, no data about its reproductive habits and behavior, no field observations and literature reports. We can only refer to the studies on breeding ecology in zoos (Gao et al., 2013), disease diagnosis (Zhang et al., 1997, Dong et al., 2010), rescue of injured bird (Zhu, 2008), genetic study (Li et al., 2013), anatomical observation (Liu et al., 1998, Wang et al., 2008) and toxicology test (Zhang et al., 2005). Comparing to our neighboring countries, we are far from the same scope 
Типичный вид на гнездовой участок грифа в горах Тянь-Шаня. Фото МаМинга.

A typical view of the nesting territory of the Cinereous Vulture in the Tien Shan Mountains. Photo by MaiMing.

Рис. 1. Область иссиедований и 4 гнезда чёрного гриса (Aegypius monachus), расположенные в южной части Тянь-Шаня.

Fig. 1. The research area and 4 nests of the Cinereous Vulture (Aegypius monachus) located in the southern part of Tien Shan Mountains. о местообитаниях и поведении, нет никаких Аанных о наблюдениях в Аикой природе, также как и нет публикаций об этом. Мы можем ссыиаться только на Аанные о гнезАовой биологии в 30опарках (Gao et al., 2013), диагностику заболеваний (Zhang et al., 1997; Dong et al., 2010), суучаи спасения птиц в природе (Zhu, 2008), свеления по генетике (Li et al., 2013), анатомии (Liu et al., 1998; Wang et al., 2008) и токсикологические тесты (Zhang et al., 2005), в отличие от соседних стран, где имеются многочисленные публикации об экологии и биологии этого вила (Reading et al., 2005; Kim et al., 2007; Batbayar et al., 2008; Zhatkanbaev, 2011; Karyakin et al., 2009a; 2009b; 2014; Shnayder, 2015; Kenny et al., 2015).

В 2015 г. был начат исследовательский проект при подцержке Национаиьного сонАа естественных наук Китая (№ 31572292) по наблюдению за четырьмя гнёздами грифов в центраиьной части Тянь-Шаня в Синьцзяне, на запаце Китая, с использованием инсракрасных фотоловушек и GPS/GSM телеметрии.

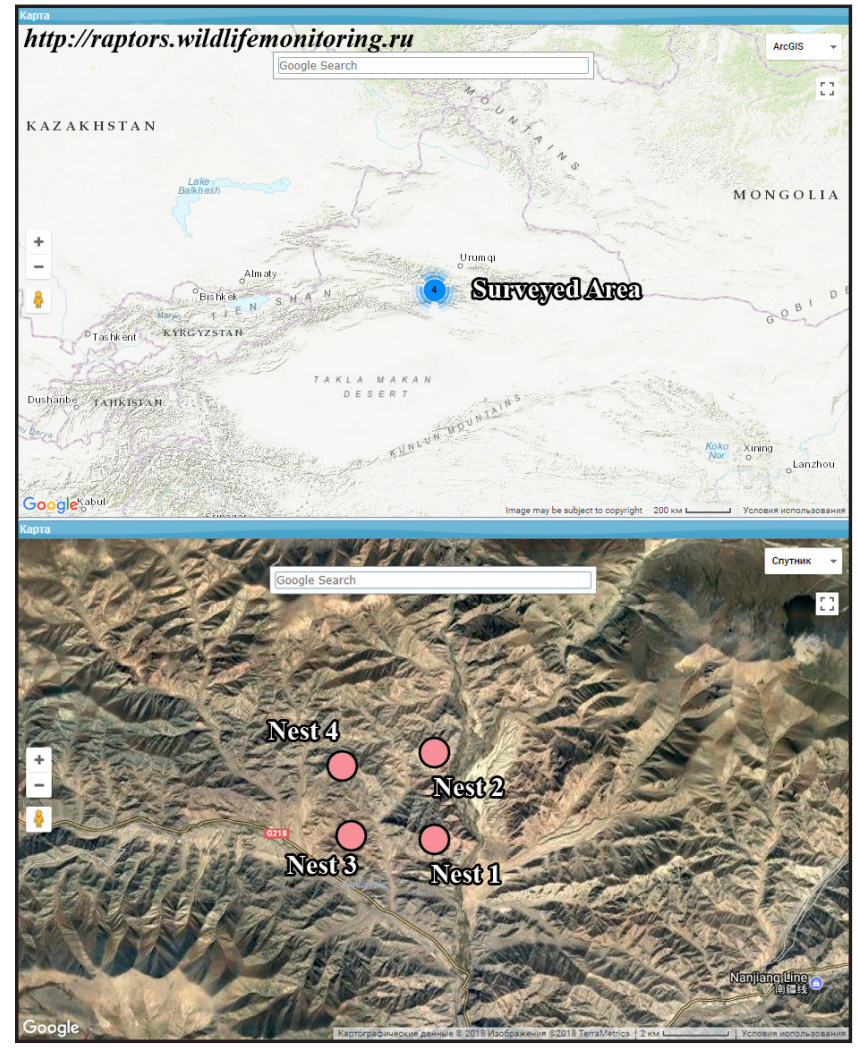

of research (Reading et al., 2005; Kim et al. 2007; Batbayar et al., 2008; Zhatkanbaev, 2011; Karyakin et al., 2009a; 2009b; 2014; Shnayder, 2015; Kenny et al., 2015).

In 2015, we started a new project founded by the National Natural Science Foundation of China (No. 31572292), and for the first time we described 4 nests of the vulture using infrared camera-traps in the middle of Tien Shan Mountains in Xinjiang, the west of China. We also tracked activity of the juvenile birds by GPS/GSM telemetry.

\section{Study Area}

Tien Shan is one of the largest mountainous in Central Asia; the highest peak is Tomur with the altitude of $7435 \mathrm{~m}$. The mountains extension from east to west is about $2600 \mathrm{~km}$, with more than 65 \% located in China, and the rest - in Kazakhstan, Kyrgyzstan and Uzbekistan.

The research area is located in the south of Tien Shan Mountains on an altitude of 2000-3000 $\mathrm{m}$, to the north from G218 national highway. The geographical coordinates are $42^{\circ} 30^{\prime}-43^{\circ} 10^{\prime} \mathrm{N}$ and $86^{\circ} 00^{\prime}-$ $86^{\circ} 40^{\prime} \mathrm{E}$ (fig. 1). The temperature in this area changes significantly. This territory used as a winter pasture for local herdsmen. The main local herdsmen are Mongolian, their religion is Buddhism and the sky-burial customs are still retains in the region. Large mammals inhabited the region are Ibex (Capra ibex), Argali (Ovis ammon), Eurasian Lynx (Lynx lynx), Wolf (Canis lupus) and Marmot (Marmota bobac), and common bird species are Himalayan Griffon (Gyps himalayensis), Lammergeier (Gypaetus barbatus), Golden Eagle (Aquila chrysaetos), Chukar (Alectoris chukar), Himalayan Snowcock (Tetraogallus himalayensis), Eagle Owl (Bubo bubo) and Redbilled Chough (Pyrrhocorax pyrrhocorax). 


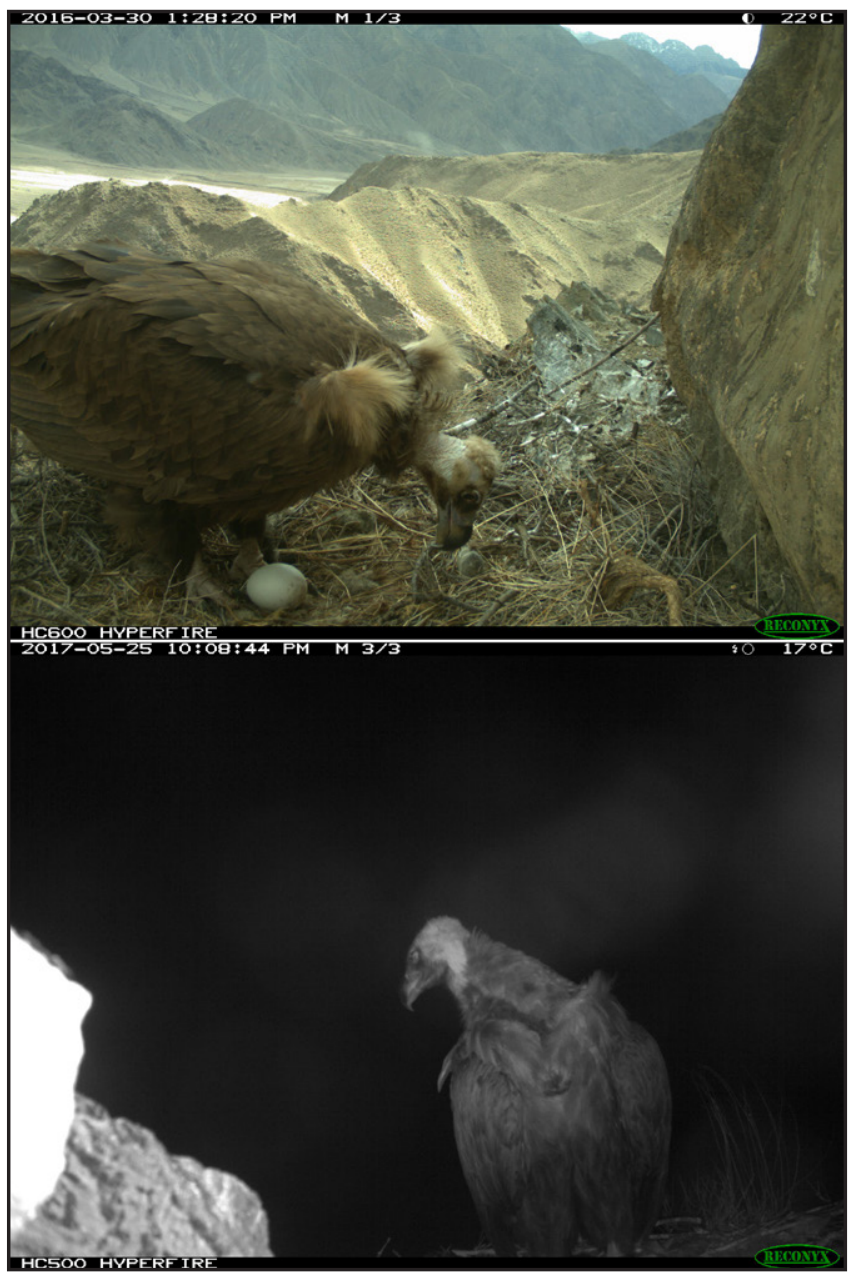

Область исследования

Тянь-Шань - одна из самых высоких горных систем в Центраиьной Азии, вершина г. Пик Победы (Томур), высота 7435 м. Горы простираются с востока на запац примерно на
Ночная (внизу) и дневная (вверху) съёмка фотоловушками Rexonyx HC600 на гнёдах грисра. Вверху - гнезАо № 1 в марте 2016 г., внизу - гнездо № 3 в мае 2017 г. Фото предоставлено МаМингом.

Night (bottom) and day (upper) photos from vulture's nests by camera-traps Rexonyx HC60O. At the top nest No. 1 in March 2016, at the bottom - nest No. 3 in May 2017. Photos from MaMing.

\section{Methods}

We used telescopes to locate nests in mountains. Additional questionnaire investigation among local herdsmen provides us with the information over the past years. During the study period, we were able to found only 4 nesting sites, and set up 7 Bushnell HD and Rexonyx HC600 camera-traps. Cameras were set on about $5 \mathrm{~m}$ from the nests. During the study period we got more than 110 thousands photographs and 90 minutes of video.

To provide the regular observations without disturbing incubating bird we set up the observation point on the hillside in more than $600 \mathrm{~m}$ from the nest. Observations were conducted by means of binoculars (Minox BV 10×42) and telescopes (CarlZeiss Diascope 85). The behavior of adult and young bird was recorded by focus animal sampling method and full event recording. The observations started from 5:30 a.m. and lasted until 7:30 p.m.; observations were conducted for more than 40 days making in total more than 500 hours.

At the end of July one nestling from the nest No3 (table 1) was tagged with GPS/ GSM datalogger. We received information on its movements until October.
Гнездо грисра № 3 в марте 2017 г. (вверху) и птенец в этом гнезде в апреле (внизу слева) и в мае 2017 г. (внизу справа).

Фото МаМинга.

Nest of the Cinereous Vulture No. 3 in March 2017 (upper) and nestling in the same nest in April (bottom at the left) and May 2017 (bottom at the right). Photos by MaMing.

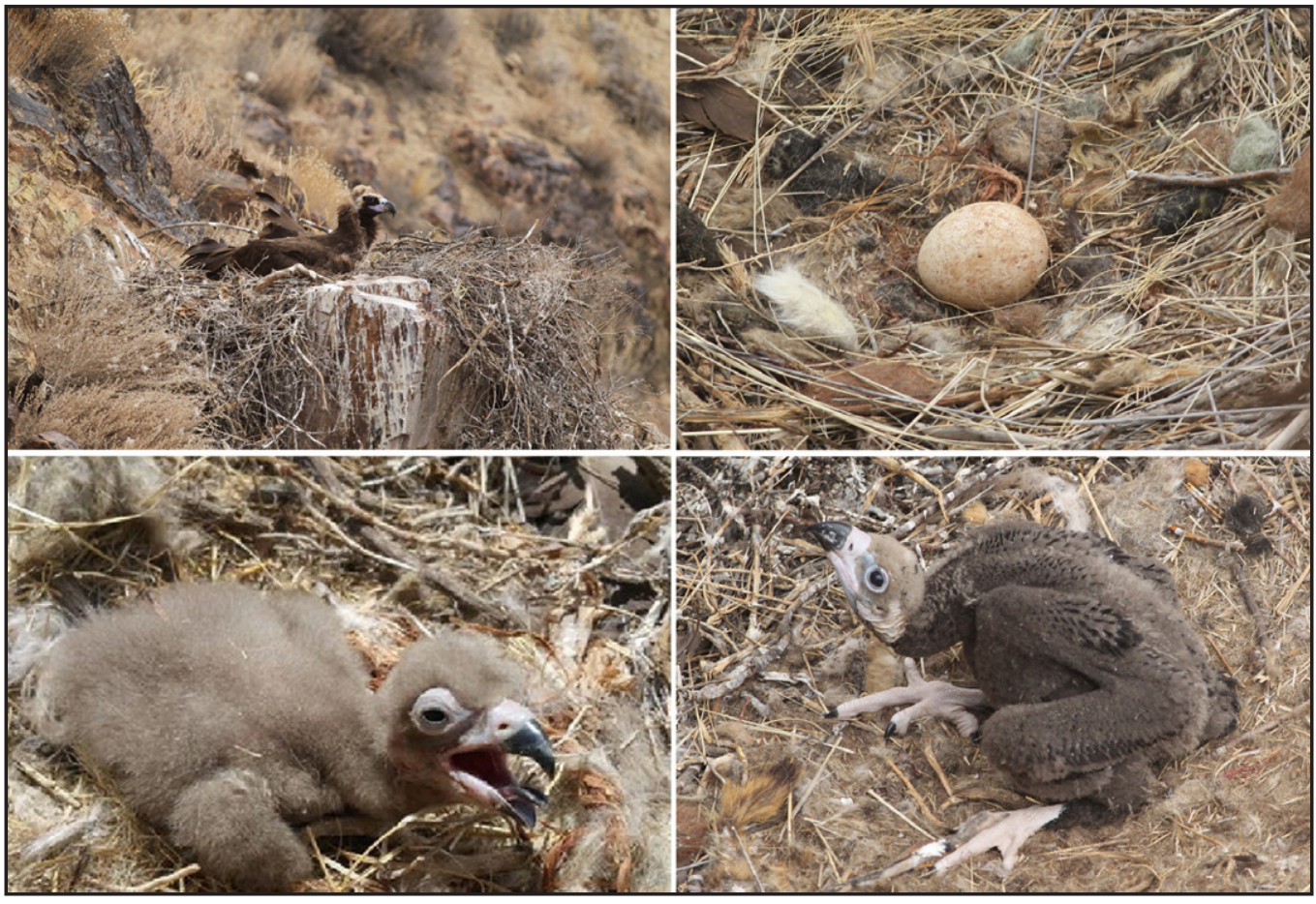




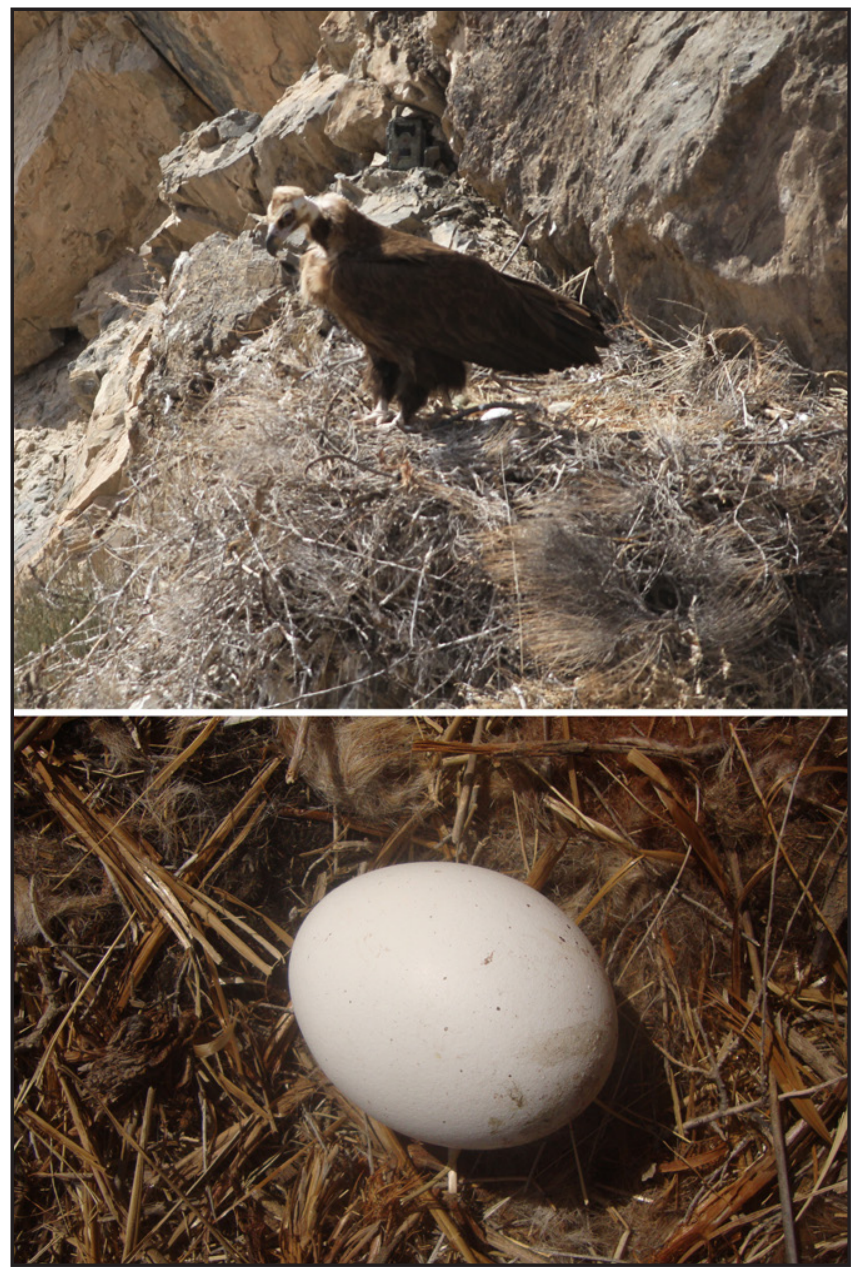

Гнездо грисра № 1 в марте 2016 г. Фото МаМинга.

Nest No. 1 of the Cinereous Vulture in March 2016. Photos by MaMing.

2600 км, более 65 \% лежит в Китае, а остаиьная часть - в пограничных районах Казахстана, Кыргызстана и Узбекистана.

Область исследований расположена в южной части Тянь-Шаня на высоте 2000-3000 м нах ур. м, к северу от национаиьной автомагистраии G218. Геограсрические координаты

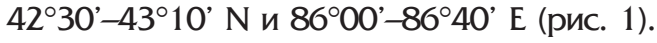
Температура в этой области сильно варьирует. Территория используется в качестве зимних пастбиш местными скотоводами. Местные Скотоводы, в основном монголы, - будАисты, по-прежнему практикуюшие небесные похороны. ЗАесь обитают такие крупные миекопитающие как козерог (Capra ibex), архар (Ovis ammon), евразийская рысь (Lynx lynx),

Табл. 1. Характеристики гнёзд чёрного грифра (Aegypius monachus) в Тянь-Шане. Table 1. Characteristic data on the nests of the Cinereous Vulture (Aegypius monachus) in the Tien Shan Mts.

\begin{tabular}{llrrr}
\hline Date & $\begin{array}{r}\text { Location } \\
\text { Nata }\end{array}$ & $\begin{array}{r}\text { Elevation } \\
\text { Высота } \\
\text { H.y.м. }\end{array}$ & $\begin{array}{r}\text { Clutch size } \\
\text { Размер } \\
\text { кһaАки }\end{array}$ \\
\hline No-1 & $26 / 03 / 2016$ & N 42.90, E 86.33 & $2352 \mathrm{~m}$ & 1 \\
No-2 & $13 / 04 / 2016$ & N 42.92, E 86.40 & $2400 \mathrm{~m}$ & 1 (Nestling) \\
No-3 & $28 / 03 / 2017$ & N 42.90, E 86.30 & $2385 \mathrm{~m}$ & 1 \\
No-4 & $18 / 04 / 2017$ & N 42.93, E 86.32 & $2750 \mathrm{~m}$ & 1 (Lost) \\
\hline
\end{tabular}

Data statistics was carried out in the Microsoft Excel and the R Program.

\section{Results \\ Nest Site Selection}

In the study area, vulture's nest site selection is similar to those in Tian Shan and Altai mountains (Karyakin et al., 2009a; Karyakin et al., 2009b; Zhatkanbaev, 2011) and differ from those in Mongolia, where $33 \%$ of pairs nest on trees (Reading et al., 2005). We found four nests; all located on cliffs, on open protruding platforms. High of cliffs vary from 9 to 18 meters, the elevation is between $2300 \mathrm{~m}$ and $2900 \mathrm{~m}$ (table 1). Nests were built of tree branches, outer diameter varied from $1.1 \mathrm{~m}$ to $1.6 \mathrm{~m}$. The bedding materials included grass, bones, skins, wool and other mammal's hair.

\section{Density of Nests}

The vultures do not seem to be a colonial species, but they make sparse breeding communities, with distance between nests is $1-3 \mathrm{~km}$. Thus, within 100 square kilometers there could be up to 4 nests (estimated density 2-4 nests $/ 100 \mathrm{~km}^{2}$ ) (fig. 1). Usually Cinereus Vultures lay eggs from the end of February to early March, the number of clutch is often only one egg (in this study $n=4$ ), eggshell is white; measurements of the egg are the following: diameter is $72 \times 96 \mathrm{~mm}$, weight is about $210 \mathrm{~g}$. Clutch is incubated by both parents, incubation period vary from 52 to 56 days. In our study vulture breeding success rate was $25 \%$.

\section{Brood Stage}

Chicks hatched on April 13, weighing about $160 \mathrm{~g}$. Male and female feed the chick in turn vomiting food mouth-to-mouth from parent to nestling, showing a major difference from other large birds of prey. The number of daily feedings decrease as the nestling grows, but the amount of nutrition increases gradually. On May 17, the young bird weighted about $1.50 \mathrm{~kg}$; on June 14$5.65 \mathrm{~kg}$; on July $3-8.45 \mathrm{~kg}$; on July $14-8.56 \mathrm{~kg}$ (close to the adult's body weight). Brood period in this species is relatively long - it needs 90 to 105 days for young birds to fledge. Young birds leave the nest from late July to early August. According to the infrared camera shooting and satellite tracking, young bird did not really leave the nest area until October (fig. 2). Juvenile bird often returns to the nest area to be fed by the adult birds. Therefore, the entire brooding period is up to 200 days.

\section{Feeding habits and diet}

The daily number of feeding decrease while the nestling grows. From April to May adult 
волк (Canis lupus), сурок-байбак (Marmota bobac), а также типичные птицы высокогорий - кумай (Gyps himalayensis), бородач (Gypaetus barbatus), беркут (Aquila chrysaetos), кекиик (Alectoris chukar), гималайский улар (Tetraogallus himalayensis), фрилин (Bubo bubo) и киушица (Pyrrhocorax pyrrhocorax).

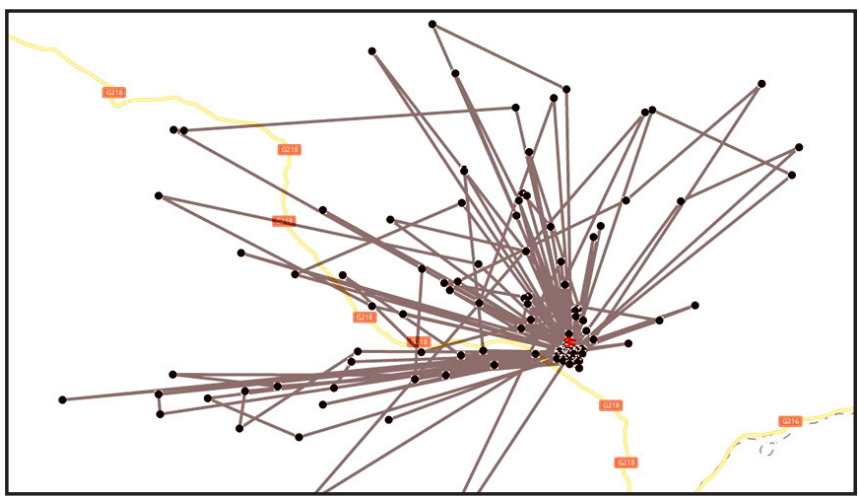

\section{Методы}

Опираясь на известные особенности гнёзд, мы использоваии телескопы мяя их поиска в горах. Поиск гнёзд - наиболее трудная работа в Тянь-Шане. Мы занимачись анкетированием местных пастухов, мия получения информации о встречах грисов за многие годы. За весь период исследований было найАено только 4 гнезАа. За ними и вели наблюмение с помощью 7 фотоловушек Bushnell HD и Rexonyx HC600, установленных на

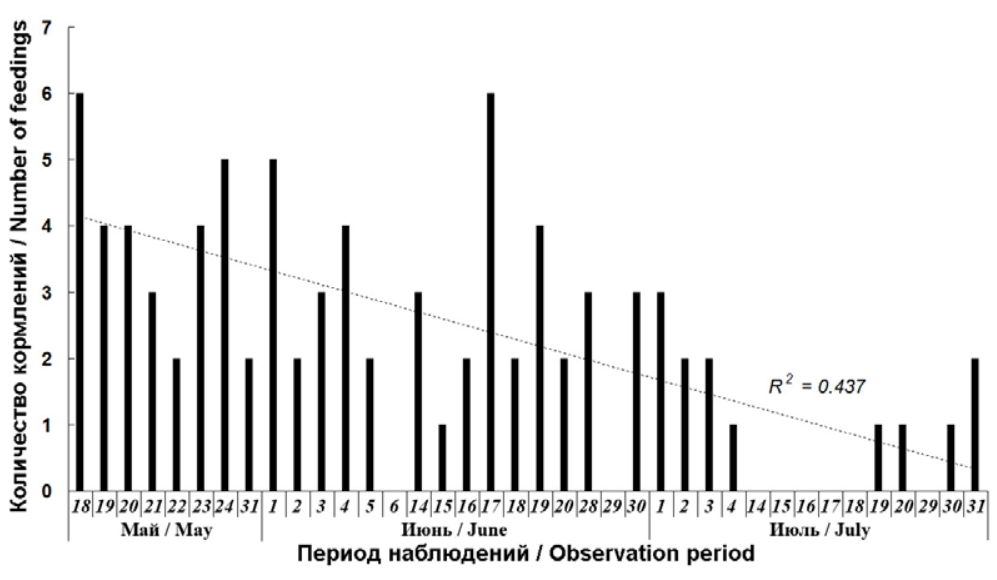

Рис. 3. Частота кормиений птенца взросиыми птицами за 3-месячный период наблюдений.

Fig. 3. Frequency of feeding of the nestling by adult birds for a 3-month observation period.

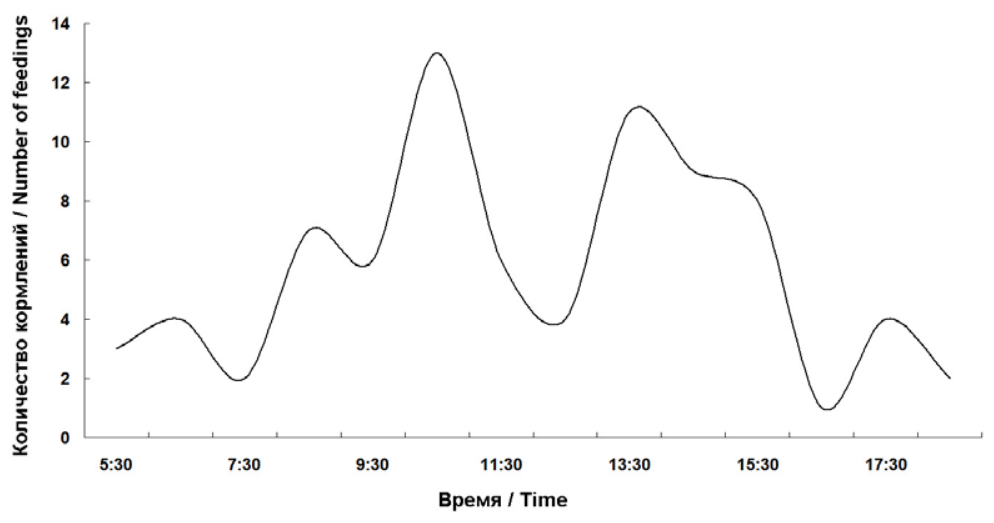

Рис. 4. Частота кормиения птенца взросыыми птицами в течение Аня.

Fig. 4. Frequency of feeding of the nestling by adult birds during the day.

Рис. 2. Перемешения сиётка из гнезда № 3, помеченного GPS/GSM трекером, с конца июля по октябрь в этот период он не покицаи гнездовой участок.

Fig. 2. Movements of the fledgling from the nest No. 3, tagged by GPS/GSM datalogger from the end of July to October; during this period juvenile bird remained in the nesting area.

fed the nestling 4-6 times a day, while in JuneJuly this number drops to 0-1 times a day (fig. 3). From May to end of July number of daily feedings decrease significantly $\left(R^{2}=0.437\right)$ (fig. 3). In the later period, we saw the young bird often starving - parents spent a lot of time for foraging and feeding time delayed.

Most of food nestling received during certain hours each day - the first peak of feeding we observed between 10:00 and 11:00 a.m., followed by the second peak at 1:00-3:30 p.m. Thus, we can allocate two peaks in the daily feeding (fig. 4).

The diet of nestling consists of small mammals in addition to the carcasses of large animals. On one nest under study we repeatedly saw corpses of small mammals such as Spermophilus sp. and Mustela sp. We also found skulls and fresh skins of Marmota sp. on the same nest as well (fig. 5).

\section{Additional observations}

We encountered Chough (Pyrrhocorax pyrrhocorax), Magpie (Pica pica) and Eagle Owl (Bubo bubo) in the nests of Cinereous Vulture. We assume that they visit nests in search for some food. Convidae visited nets rather frequently and in some cases they could be the cause for the low success breeding rate in vultures.

\section{Conclusion}

Food insufficient and hunger are the main reasons for the relatively low breeding success of Cinereous Vultures.

We hope that our research can bring more attention towards vultures, and we suggest the local government to adopt effective measures to protect vultures such as establishing protect- 
Рис. 5. Некоторые пишевые остатки в гнезде.

Fig. 5. Some food remains in the nest. расстоянии примерно 5,0 м От гнёзА. Всего было снято 110 тысяч фотограсрий и 90 минут видео.

Чтобы иск^ючить беспокойство птиц во время насиживания, регулярные наблюдения и измерения производили с расстояния более 600 м от гнезда - с противоположного скиона хомма, ми чего использоваии бинокии (Minox BV $10 \times 42$ ) и телескопы (CarlZeiss Diascope 85). Повеление взросАых и молодых птиц описываии как по выборке регистраций, полученных фотоловушками, так и по полной регистрации событий, полученных в ходе визуаиьных наблюдений или интерваиьной съёмки. НаблюАения проводились с 5:30 $о 0$ 19:30 более 40 Аней, обшей продолжительностью более 500 часов. А с конца июля по октябрь слётка из гнезАа № 3 (табл. 1) отслеживаии с помошью GPS/GSM трекера. Статистическая обработка данных выполнена в Microsoft Excel и программе $\mathrm{R}$.

\section{Результаты}

\section{Места расположения гнёзц}

На обследованной территории места, гле грисы устраивают гнёзда, схожи с таковыми в Тянь-Шане и на Аитае (Karyakin et al., 2009а; Karyakin et al., 2009b; Zhatkanbaev, 2011) и несколько отличаются от таковых в Монголии, гле 33 \% пар гнездятся на деревьях (Reading et al., 2005). Все найденные нами 4 гнезда грисов расположены на скаиах. Высота скаи

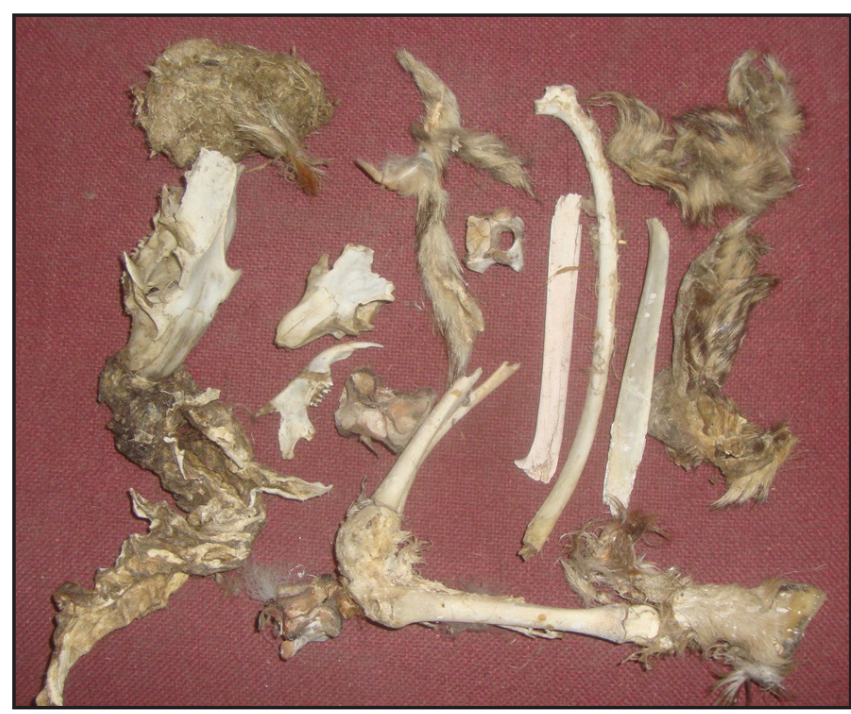

Моменты кормления птенца в июле 2017 г. (вверху) и в сентябре 2017 г. (внизу). Фото предоставлено МаМингом.

Feeding of the nestling in July 2017 (upper) and in September 2017 (bottom). Photos from MaMing.

ed areas, setting up "feeding station", encouraging and restoring the local Mongolian skyburial customs (MaMing et al., 2016; MaMing et al., 2017) as soon as possible.

\section{Acknowledgments}

We thank our team members Cai Wujiafu, Tao Yonghai, Tie Hu (Arsilang), Cai Kai (a herdsman) and his family, Arlai (a guider), Xu Guohua, Ding Peng, Xu Feng, Zhang Tong, Tong Yuping, Andrew Dixon, Paul Buzzard and others who helped us during the field expedition for their contribution to this study. Special thanks to the cooperation team from Wuhan University - Lu Xin, Zhao Huabin, Zou Dahu, Xie Huanwang and Wang Yi.

The project was supported by the National Natural Science Foundation of China (No. 31572292, No. 31272291).

\section{References}

Batbayar N., Reading R., Kenny D. Migration and movement patterns of Cinereous Vultures in Mongolia. - Falco, 2008. 32: 5-7.

Dong Y.X., Li J.F., Hu Z.F. Diagnosis and etiology analysis of gout of Cinereous Vulture. - Chinese Journal of Veterinary Medicine. 2010. 46 (9): 32-33. 


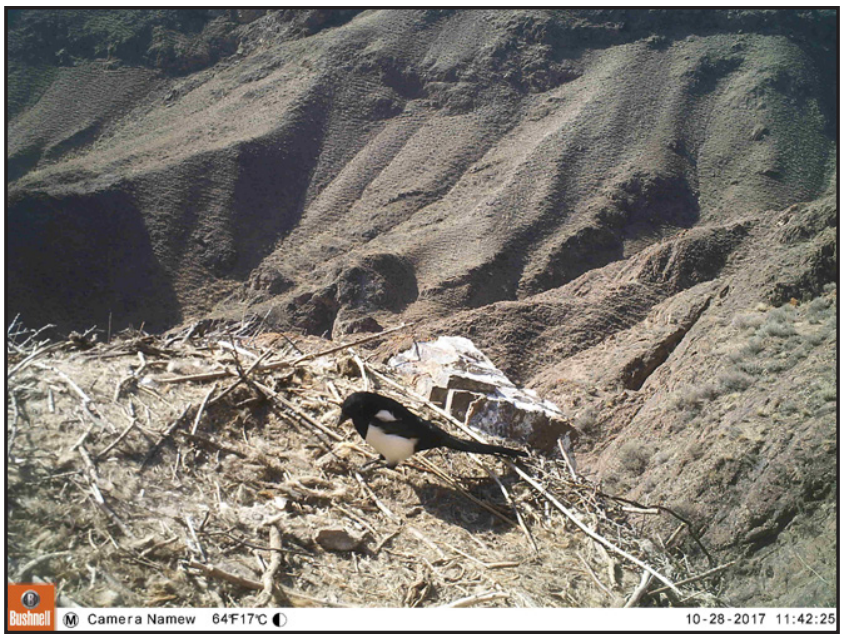

Сорока (Ріса ріса), ишушая на гнезде грифов пишу. Фото предоставлено МаМингом

Magpie (Pica pica) on the nest of the Cinereous Vulture searching for food. Photos from MaMing варьирует от 9 Ао 18 м, высота над ур. м от 2300 м до 2900 м (табл. 1). Чаше гнёзда построены из веток на выступающих полках. Гнездовая постройка огромная - диаметром от 1,1 м $А$ 1,6 м, выстилка гнезда вкиючает траву, кости, шкуры, шерсть и волосы крупных животных.

\section{Пиотность гнезАовой группировки}

Грисы, по-видимому, не являются колониаиьными, но живут разреженными гнездовыми сообшествами, гле расстояние между гнёздами составляет 1-3 км, таким образом,

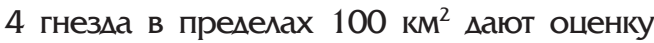

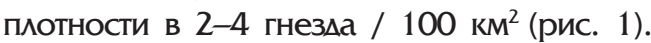
Обычно грисы делают киамку в конце февраяя - начале марта, число яиц в киамке только одно $(n=4)$. Яичная скорлупа белого цвета, диаметр яйца 72×96 мм, вес около 210 г. Родители насиживаии поочерёдно, инкубационный период составил от $52 \Delta 0$ 56 Аней. Успех размножения составил $25 \%$.

\section{Период выкарммивания птенцов}

Птенец вылупился 13 апреля, его вес составляи 160 г. Грисы отличаются от Аругих крупных хишных птиц тем, что самец и самка кормят поочерёАно, отрыгивая пишу изо рта в рот. По мере роста птенца, число кормиений в сутки уменьшается, при этом количество корма постепенно увеличивается. Вес птенца составмяи: 17 мая - около 1,50 кг, 14 июня - 5,65 кг, 14 июля - 8,56 кг (близок к весу взросых).

Период выкармиивания птенцов на гнёзАах относительно Аминный - от 90 Ао 105 мней, молодые птицы вылетают, самое раннее, в конце июля или в начале августа. Согласно снимкам инфракрасной камеры и Аанных спутникового слежения, слёток в августе - октябре не покидаи гнездовой участок (рис. 2) - он периодически возврашаися на гнездо, гле его кормили родители. Таким образом, весь период выкармиивания Амит-
Gao F., Ji J.W., Tian H.J. Daily behavior and time allocation of activities of captive Vultures during breeding period. - Wetland Science \& Management. 2013. 9 (1): 65-68.

Karyakin I.V., Bachtin R.F., Vazhov S.V., Barashkova A.N., Nikolenko E.G., Shnayder E.P., Bekmansurov R.H. New data on the breeding group of Cinereous Vulture in Altai Republic, Russia. - Raptors Conservation. 2014. 28: 100-102. DOI: $10.19074 / 1814-8654-2014-28-100-102$.

Karyakin I.V., Konovalov L.I., Grabovskiy M.A., Nikolenko E.G. Vultures of the Altai-Sayan Region. - Raptors Conservation. 2009a. 15: 37-65.

Karyakin I.V., Nikolenko E.G., Vazhov S.V., Bekmansurov R.H. New data on vultures of the Altai Mountains, Russia. - Raptors Conservation. 2009b. 16: 173-176.

Kenny D., Kim Y.J., Lee $H$. Blood lead levels for Eurasian Black Vultures (Aegypius monachus) migrating between Mongolia and the Republic of Korea. - Journal of Asia-Pacific Biodiversity. 2015. 8 (1): 199-202.

Kim J.H., Chung O.S., Lee W.S. Migration routes of Cinereous Vultures (Aegypius monachus) in northeast Asia. - Journal of Raptor Research. 2007. 41 (2). P. 161-165.

Li B., Liu G., Zhou L.Z. Complete mitochondrial genome of Cinereous vulture Aegypius monachus (Falconiformes: Accipitridae). - Mitochondrial DNA, 2013. 20(6): 910-911.

Liu Z.K., Liu J.H., Huang F.S. Anatomical observation of the digestive system of Aegypius monachus. - Journal of Economic Animal. 1998. 2 (3): 39-43.

MaMing R., Xu G.H., Wu D.N. Vultures in Xinjiang. - Beijing: Science Press. 2017.

MaMing R. and Xu G.H. Status and threats to vultures in China. - Vulture News. 2015. 68: 3-24.

MaMing R., Li Lee, Xiaomin Yang, Paul Buzzard. Vultures and sky burials in the Qinghai-Tibet Plateau. - IUCN Vulture News. 2016. 71: 22-35.

Reading R.P.; Amgalanbaatar S., Kenny D., Dashdemberel B. Cinereous Vulture nesting ecology in Ikh Nartyn Chuluu Nature Reserve, Mongolia. - Mongolian J. Biol. Sci. 2005. 3 (1): 13-19.

Shnayder E.P. New Data about breeding of the Cinereous Vulture in the Republic of Altai, Russia. - Raptors Conservation. 2015. № 31: 153-155. DOI: 10.19074/1814-8654-2015-31-153-155

Wang X., Wen C.F., Zhang Z.H. Anatomical characteristics on the skeleton of Cinereous Vulture. - Chinese Journal of Zoology. 2008. 43 (4). P. 109-113.

Ye X.T. Distribution and status of the Cinereous Vulture Aegypius monachus in China. - Birds of Prey Bulletin. 1991. 4 (1): 51-56.

Zhang Q., Tang X.S., Wu H., Pan L.Y. A case of mycoplasma disease on Cinereous Vulture. China Poultry. 1997. 19 (1): 41-41.

Zhang X.Y., Li S.Q., Liu S.C. Sensitivity tests of D-type botulism rodenticides on the predators such as Lammergeier and Eurasian Black Vulture. - Sichuan Caoyuan (Prataculture \& Animal Husbandry). 2005. 36 (3): 19-19.

Zhatkanbaev A.Zh. Surveys of Breeding biology of the European Black Vulture in the SouthEastern Kazakhstan. - Raptors Conservation. 2011. 23: 182-193.

Zhu G.J. Ambulance a Cinereous Vulture in Foping County. - Shaanxi Forestry. 2008. 33 (1): 47-47. 
ся Ао 200 Аней (после вылета из гнезда птенец АОкармиивается около 80-90 дней).

\section{Особенности питания}

Ежедневное время кормиения родителями постепенно уменьшаиось: с 4-6 раз в день в

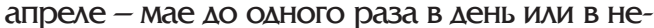
сколько Аней в июне - июле (рис. 3). С мая по конец июля количество суточных кормиений Аостоверно уменьшилось $\left(R^{2}=0,437\right)$ (рис. 3).

В более поздний период мы наблюдаии, что молодая птица часто голодаяа, родители подолгу добывами корм, кормиение зацерживалось. В Аневном питании было два пика

\section{Закиючение}

Недостаток пиши и голод являются причиной низкого успеха размножения.

Мы надеемся, что наши исследования могут привлечь внимание к проблеме выживания грисов. Местное правительство Аолжно как можно скорее принять эфффективные меры м^я охраны грифров, такие как выделение ООПТ, создание подкормочных плошадок, а также поошрение и восстановление местных монгольских обычаев небесных похорон (MaMing et al., 2016; MaMing et al. 2017).
Пара взросиых грисоов и птенец на гнезде в мае 2017 г. (вверху сиева), взросый грисф с птенцом на гнезде в июне (вверху справа), птенец посие мечения GPS/GSM трекером в июле (внизу слева) и сиёток, посешаюший гнезАо, в октябре (внизу справа). Фото предоставлено МаМингом. Breeding pair of Cinereous Vultures and their nestling in the nest in June 2017 (top at the left), adult and nestling in the nest in June 2017 (top at the right), nestling after tagging with the GPS/GSM datalogger in July 2017 (bottom at the left), fledgling of the Cinereous Vulture visited his nest in October (bottom at the right). Photos from MaMing.

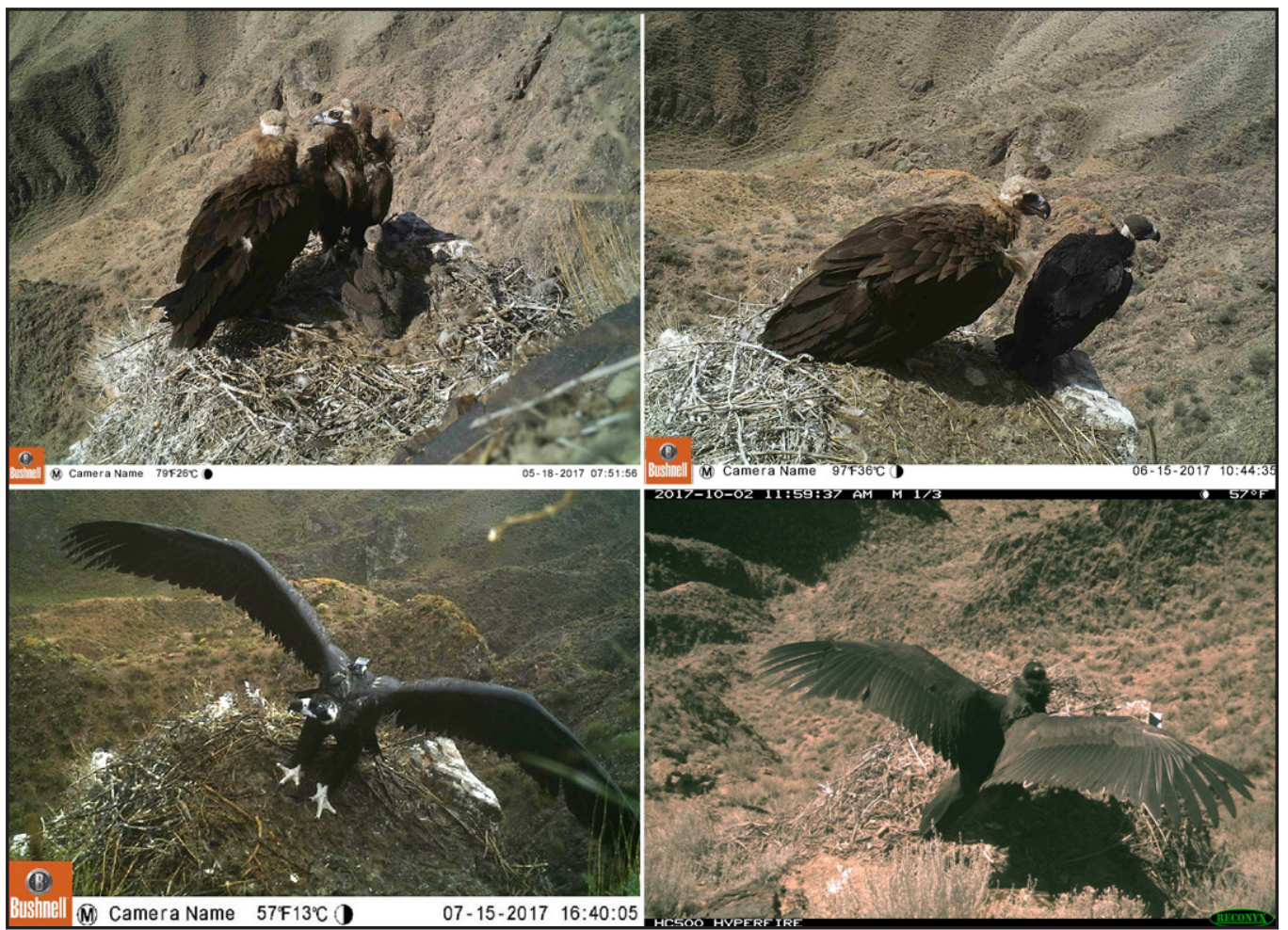

(рис. 4): первый пик кормиения птенца был в 10:00-11:00, второй пик - в 13:00-15:30.

Питание грисров состояио не только из крупной пахаии, а также из мелких животных. Один из наших наблюдателей неоднократно видел птенца в гнезде с мелкими животными, такими как сусиики (Spermophilus sp.) или мелкие куньи (Mustela sp.). В гнезде быии найдены черепа сурков (Marmota sp.), сусииков, и свежие шкурки этих зверьков (рис. 5).

\section{Дополнительные наблюдения}

Мы сриксироваии киушиц (Pyrrhocorax pyrrhocorax), сорок (Рica pica) и филина (Bubo bubo) на гнезде грисров, куда они предположительно прилетаяи в поисках пиши. Врановые часто посешаии гнездо грисра - в ряде случаев они могут явиться причиной низкого уровня успеха размножения грисоов.

\section{Благодарности}

Выражаем благодарность членам нашей команды: Цай Вуцзясру (Cai Wujiafu), Тао Юнхай (Тао Yonghai), Тай Ху (Tie Hu), пастуху Цай Кай (Cai Kai) и его семье, проводнику Арлаи (Arlai), Сюй Гохуа (Xu

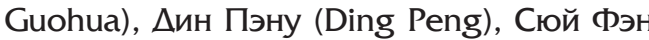
(Xu Feng), Чжан Тонгу (Zhang Tong), Тонг Юпингу (Tong Yuping), Энарю Аиксону (Andrew Dixon), Полу Баззарду (Paul Buzzard) и Аругим, кто помогаи нам в экспедициях. Особая благодарность команде партнёров из Уханьского университета: ^у Синь (Lu Xin), Чжао Хуабин (Zhao Huabin), Цзоу $\triangle$ axy (Zou Dahu), Ce Хуанван (Xie Huanwang) и Ван $И$ (Wang Yi). научным фооном Китая (№ 31572292 , № 31272291 ).
Проект был подцержан Национальным 